\title{
Front Matter: Volume 10175
}

, "Front Matter: Volume 10175," Proc. SPIE 10175, Electron Technology Conference 2016, 1017501 (28 December 2016); doi: 10.1117/12.2270351

SPIE. Event: Electron Technology Conference ELTE 2016, 2016, Wisla, Poland 


\title{
PROCEEDINGS OF SPIE
}

\section{Electron Technology Conference 2016}

\author{
Barbara Swatowska \\ Wojciech Maziarz \\ Tadeusz Pisarkiewicz \\ Wojciech Kucewicz \\ Editors
}

11-14 September 2016

Wisła, Poland

\author{
Organized by \\ Department of Electronics; Faculty of Computer Science, Electronics and \\ Telecommunications; AGH University of Science and Technology, Kraków (Poland) \\ Sponsored by \\ Fitech Sp. z o.o., Sucha Beskidzka (Poland) \\ COMEF Scientific and Research Equipment Sp. z o.o., Katowice (Poland) \\ Cooperating Organization and Publisher \\ SPIE
}


The papers in this volume were part of the technical conference cited on the cover and title page. Papers were selected and subject to review by the editors and conference program committee. Some conference presentations may not be available for publication. Additional papers and presentation recordings may be available online in the SPIE Digital Library at SPIEDigitallibrary.org.

The papers reflect the work and thoughts of the authors and are published herein as submitted. The publisher is not responsible for the validity of the information or for any outcomes resulting from reliance thereon.

Please use the following format to cite material from these proceedings:

Author(s), "Title of Paper," in Electron Technology Conference 2016, edited by Barbara Swatowska, Wojciech Maziarz, Tadeusz Pisarkiewicz, Wojciech Kucewicz, Proceedings of SPIE Vol. 10175 (SPIE, Bellingham, WA, 2016) Seven-digit Article CID Number.

ISSN: 0277-786X

ISSN: 1996-786X (electronic)

ISBN: 9781510608436

ISBN: 9781510608443 (electronic)

Published by

SPIE

P.O. Box 10, Bellingham, Washington 98227-0010 USA

Telephone +1 3606763290 (Pacific Time) · Fax +1 3606471445

SPIE.org

Copyright @ 2016, Society of Photo-Optical Instrumentation Engineers.

Copying of material in this book for internal or personal use, or for the internal or personal use of specific clients, beyond the fair use provisions granted by the U.S. Copyright Law is authorized by SPIE subject to payment of copying fees. The Transactional Reporting Service base fee for this volume is $\$ 18.00$ per article (or portion thereof), which should be paid directly to the Copyright Clearance Center (CCC), 222 Rosewood Drive, Danvers, MA 01923. Payment may also be made electronically through CCC Online at copyright.com. Other copying for republication, resale, advertising or promotion, or any form of systematic or multiple reproduction of any material in this book is prohibited except with permission in writing from the publisher. The CCC fee code is 0277-786X/16/\$18.00.

Printed in the United States of America.

Publication of record for individual papers is online in the SPIE Digital Library.

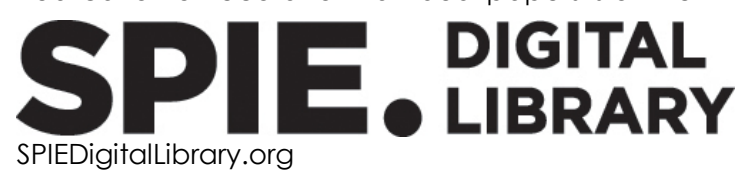

Paper Numbering: Proceedings of SPIE follow an e-First publication model. A unique citation identifier (CID) number is assigned to each article at the time of publication. Utilization of CIDs allows articles to be fully citable as soon as they are published online, and connects the same identifier to all online and print versions of the publication. SPIE uses a seven-digit CID article numbering system structured as follows:

- The first five digits correspond to the SPIE volume number.

- The last two digits indicate publication order within the volume using a Base 36 numbering system employing both numerals and letters. These two-number sets start with $00,01,02,03,04,05$, $06,07,08,09,0 A, 0 B \ldots$. OZ, followed by 10-1Z, 20-2Z, etc. The CID Number appears on each page of the manuscript. 


\title{
Contents
}

\author{
vii Authors \\ ix Conference Committees \\ xiii Introduction
}

REVIEW PAPER

1017502 Electron Technology: ELTE 2016 [10175-56]

INVITED

1017503 Electron beam throughput from raster to imaging (Invited Paper) [10175-48]

MICRO- AND NANOELECTRONICS

1017504 Integrated testing system FiTest for diagnosis of PCBA [10175-16]

1017505 Silicon pixel detector prototyping in SOI CMOS technology [10175-31]

1017506 Voiding in lead-free soldering of components with large solder pads [10175-11]

$1017507 \quad$ Manufacturing of $\mathrm{HfO}_{\mathbf{x}} \mathrm{N}_{\mathbf{y}}$ films using reactive magnetron sputtering for ISFET application [10175-34]

1017508 Effect of interface traps parameters on admittance characteristics of the MIS (metalinsulator-semiconductor) tunnel structures [10175-35]

1017509 A fully differential OTA with dynamic offset cancellation in 28nm FD-SOI process [10175-47]

$101750 \mathrm{~A}$ A $10 \mathrm{Gs} / \mathrm{s}$ latched comparator with dynamic offset cancellation in 28nm FD-SOI process [10175-54]

10175 OB Simulation of electrical characteristics of GaN vertical Schottky diodes [10175-21]

10175 OC Modeling high-frequency capacitance in SOI MOS capacitors [10175-23]

10175 OD New approach to the electrical representation of SOFC [10175-8]

10175 OE Bipolar transistor in VESTIC technology: prototype [10175-22] 
10175 OF Reactive lon Etching (RIE) of silicon for the technology of nanoelectronic devices and structures [10175-36]

10175 OG Multiplafform application for calculating a combined standard uncertainty using a Monte Carlo method [10175-27]

$10175 \mathrm{OH}$ Impact of nanocrystal(s) location on C-V-t and I-V-t characteristics of ncMOS structures [10175-44]

10175 ol CMOS standard cells characterization for open defects for test pattern generation [10175-46]

10175 0J Modeling of tunnel field effect transistor: the impact of construction parameters [10175-41]

10175 OK Printed PEDOT layers as transparent emitter electrodes for application in flexible inorganic photovoltaic structures [10175-40]

$10175 \mathrm{OL}$ Anisotropic etching of silicon in solutions containing tensioactive compounds [10175-15]

PHOTONICS

$10175 \mathrm{OM}$ Multiparametric methane sensor for environmental monitoring [10175-32]

10175 ON Effect of oxygen plasma modification on refractive index sensing with micro-cavity in-line Mach-Zehnder interferometer [10175-28]

1017500 Reflection configuration of long period grating sensor working at dispersion turning point [10175-52]

$10175 \mathrm{OP}$ Influence of the size of a micro-cavity fabricated in an optical fiber using the femtosecond laser in a form of in-line Mach-Zehnder interferometer on its refractive index sensitivity [10175-20]

$101750 Q \quad$ Optical properties of lamps with cold emission cathode [10175-39]

10175 OR Critical current and electric transport properties of superconducting epitaxial $\mathrm{Nb}(\mathrm{Ti}) \mathrm{N}$ submicron structures [10175-7]

10175 OS Polarization control based interference microwave photonic filters [10175-30]

10175 OT Transmission properties analysis of 1D PT-symmetric photonic structures [10175-19]

10175 OU Fabrication and preliminary characterization of infrared photodetectors based on graphene [10175-33]

10175 OV Boron liquid solution deposited by spray method for p-type emitter formation in crystalline Si solar cells [10175-38]

$10175 \mathrm{OW}$ Impact of structure mounting of nitride laser bars on the emitted optical power [10175-37]

$101750 X \quad$ Electromagnetic field patterning or crystal light [10175-17] 
10175 OY New silicon photodiodes for detection of the 1064nm wavelength radiation [10175-5]

$10175 \mathrm{OZ}$ 16-element photodiode array for the angular microdeflection detector and for stabilization of a laser radiation direction [10175-6]

\section{MICROSYSTEMS}

1017510 Diagnosis of electronic systems in SMT technological line [10175-10]

1017511 Detection of acetone in exhaled breath with the use of micropreconcentrator and a commercial gas sensor [10175-50]

1017512 A test structure for investigation of junctionless FETs as THz radiation sensors [10175-9]

\section{ELECTRONIC AND PHOTONIC MATERIALS}

1017513 Measurement system for resistive metal oxide sensors matrix [10175-12]

1017514 Selected electrical properties of high ohmic thick-film resistors [10175-4]

1017515 Annealing of indium tin oxide (ITO) coated optical fibers for optical and electrochemical sensing purposes [10175-51]

1017516 Characterization thin films $\mathrm{TiO}_{2}$ obtained in the magnetron sputtering process [10175-45]

1017517 Sol-gel derived antireflective structures for applications in silicon solar cells [10175-43]

1017518 Epitaxial lift-off technology of GaAs multijunction solar cells [10175-49]

1017519 Structural investigation of MF, RF and DC sputtered Mo thin films for backside photovoltaic electrode [10175-53]

$101751 \mathrm{~A}$ Technology and characterization of Thin-Film Transistors (TFTs) with a-IGZO semiconductor and high-k dielectric layer [10175-14]

10175 1B Graphene photoconductors fabricated on the substrates with different resistivity [10175-18]

$101751 \mathrm{C} \quad \mathrm{a}-\mathrm{SiC}_{\mathrm{x}} \mathrm{N}_{\mathrm{y}}: \mathrm{H}$ thin films for applications in solar cells as passivation and antireflective coatings [10175-55] 
Proc. of SPIE Vol. 10175 1017501-6

Downloaded From: https://www.spiedigitallibrary.org/conference-proceedings-of-spie on 26 Apr 2023 Terms of Use: https://www.spiedigitallibrary.org/terms-of-use 


\section{Authors}

Numbers in the index correspond to the last two digits of the seven-digit citation identifier (CID) article numbering system used in Proceedings of SPIE. The first five digits reflect the volume number. Base 36 numbering is employed for the last two digits and indicates the order of articles within the volume. Numbers start with 00, 01, 02, 03, 04, 05, 06, 07, 08, 09, OA, OB...0Z, followed by 10-1Z, 20-2Z, etc.

Bar, Jan, OR, OY, OZ

Beck, Romuald B., OC

Biernacki, Krzysztof, $0 Q$

Bock, Wojtek J., ON, 0O, OP

Bogdan, Arkadiusz, 04

Bogdanowicz, Robert, 15

Borecki, M., OM

Brudnik, Andrzej, 13

Bugiel, Szymon, 05

Butor, Marcin, 10

Caban, Piotr, 16

Czarczyński, Wojciech, OX

Czarnota, Ryszard, OY

Czerwosz, Elżbieta, OQ

Dąbrowski, Arkadiusz, 14

Dasgupta, Roma, 05

Dawidowski, Wojciech, OV

Dębowska, Anna K., ON

Dobrowolski, Rafał, OY, OZ

Domański, Krzysztof, OE, 11

Dominik, Magdalena, ON, 00, 15

Duk, M., OM

Dumiszewska, E., 18

Dziedzic, Andrzej, 14

Dziurdzia, Barbara, 06, 0D, 10

Firek, Piotr, 07, 16

Galwas, Bogdan, OS

Gierałtowska, S., 1A

Głuszko, Grzegorz, OE

Golańska, Julia, 1C

Gurnecki, Pawel, 0G

Guziewicz, M., OR

Idzik, Marek, 05

Ikraiam, Fawzi A., OC

Jakubowski, Andrzej, OB

Janik, Monika, ON, OP

Jasiński, Jakub, 08, OB, OC

Jaworski, Zbigniew, 09, 0A

Judek, J., OU

Juel, Mari, OV

Kalenik, Jerzy, $0 Q$

Kamiński, Maciej, 16

Kapusta, Piotr, 05

Karasiński, Paweł, 17

Kaszub, W., 18

Klimov, Andrii, OR, OY, OZ

Kłos, Helena, OY, OZ

Kluska, Stanisława, 1C

Knyps, P., 18
Koba, Marcin, ON, OP

Kociubiński, A., OM

Kolkovsky, $\mathrm{V}_{\text {., }} \mathrm{OR}$

Korwin-Pawlowski, M. L., OM

Kucewicz, Wojciech, 02, 05

Kulawik, Jan, OY

Kuźmicz, Wiesław, OE

Kwietniewski, N., OU

Lesniak, Adam, 04

Lewińska, Gabriela, 1C

Lisik, Zbigniew, OK, 1B

Łukasiak, Lidia, OB, OC

Madziar, Krzysztof, OS

Magonski, Zbigniew, OD

Majkusiak, Bogdan, 08, OF, OH, OJ

Małek, Anna K., 19

Marchewka, Michal, OR, OY, OZ

Marczewski, Jacek, 12

Marszałek, Konstanty W., 19

Maziarz, Wojciech, 11

Mazurak, Andrzej, 08, OH

Michoń, Dagmara, 11

Mierzwiński, Piotr, OE

Mikołajek, Janusz, 06

Mikulic, Predrag, 00

Mossakowska-Wyszyńska, Agnieszka, OT

Mroczyński, Robert, OF, OU, IA

Nakwaski, Włodzimierz, OW

Niedziałkowski, Paweł, 15

Nieprzecki, Marek, OY, OZ

Niewinski, Marek, OG

Ossowski, Tadeusz, 15

Panas, Andrzej, OY, OZ

Panek, Piotr, OV

Pawluczyk, Jaroslaw, 1B

Perlin, Piotr, OW

Piotrowski, J., OU

Piotrowski, Jozef, 1B

Piotrowski, Tadeusz, OY, OZ

Pisarkiewicz, Tadeusz, 02, 11

Pleskacz, Witold, 0 I

Podgorski, Jacek, 1B

Prokaryn, Piotr, $\mathrm{OZ}$

Przewłoka, A., 18

Przymęcki, Krzysztof, OK

Puzewicz, Zbigniew, OY

Róg, Piotr, 13

Ruta, Lukasz, 1B

Rydosz, Artur M., 11, 13, 19 
Rymarczyk, Joanna, $0 Q$

Sarzała, Robert P., OW

Seredyński, Bartłomiej, OR, OY, OZ

Sezemsky, Petr, 15

Sibiński, Maciej, OK

Sierakowski, Andrzej, OY, OZ

Siuzdak, Katarzyna, 15

Skolik, Marcin, 17

Słupski, Piotr, OX

Słysz, Wojciech, OR, OY, OZ

Śmietana, Mateusz, ON, 0O, OP, 15

Sobaszek, Michał, 15

Śpiewak, Patrycja, OW

Stańczyk, Szymon, OW

Stapiński, Tomasz, 1C

Stepien, Dawid, 1B

Stępińska, Izabela, $0 Q$

Stranak, Vitezslav, 15

Strupinski, W., 18

Swatowska, Barbara, OV, 1C

Synkiewicz, Beata, OY

Szczepański, Paweł, OT, OU

Szmigiel, Dariusz, OY, OZ

Tanous, D., $\mathrm{OH}$

Tatar, Adam, 14

Tomaszewski, Daniel, OE, 12

Turala, Michal, 05

Wachnicki, Ł., lA

Wasiak, Michał, OW

Węgrzecki, Maciej, OR, OY, OZ

Wielgus, Andrzej, 0

Wiśniewski, Piotr, OF, OJ

Witoński, Piotr, OT

Wozny, Janusz, 1B

Wróblewski, Grzegorz, OK

Wymysłowski, Artur, OX

Wysokiński, Piotr, 07

Zaborowski, Michał, OY, OZ, 12

Zdrojek, M., OU

Zeranska, Klaudia, 1B

Zięba, Paweł, OV

Znajdek, Katarzyna, OK

Zubel, Irena, OL

Zywno, Marek, 03 


\section{Conference Committees}

Conference Chair

Tadeusz Pisarkiewicz, AGH University of Science and Technology

(Poland)

Conference Co-chairs

Andrzej Dziedzic, Wrocław University of Technology (Poland)

Andrzej Jakubowski, Warsaw University of Technology (Poland)

Anna Piotrowska, Institute of Electron Technology (Poland)

Tadeusz Pustelny, Silesian University of Technology (Poland)

Jan Szmidt, Warsaw University of Technology (Poland)

Honorary Chair

Wiesław Woliński, Warsaw University of Technology (Poland)

Secretary of Scientific Committee

Wojciech Kucewicz, AGH University of Science and Technology

(Poland)

Scientific Committee

Romuald B. Beck, Warsaw University of Technology (Poland)

Zbigniew Bielecki, Military University of Technology (Poland)

Michał Borecki, Warsaw University of Technology (Poland)

Andrzej Brudnik, AGH University of Science and Technology (Poland)

Zbigniew Brzózka, Warsaw University of Technology (Poland)

Maciej Bugajski, Institute of Electron Technology (Poland)

Piotr Dumania, Institute of Electron Technology (Poland)

Jan Dziuban, Wrocław University of Technology (Poland)

Jan Felba, Wrocław University of Technology (Poland)

Marek Godlewski, Institute of Physics (Poland)

Leszek Golonka, Wrocław University of Technology (Poland)

Piotr Grabiec, Institute of Electron Technology (Poland)

Małgorzata Jakubowska, Warsaw University of Technology (Poland)

Włodzimierz Janke, Koszalin University of Technology (Poland)

Danuta Kaczmarek, Wrocław University of Technology (Poland)

Ryszard Kisiel, Warsaw University of Technology (Poland)

Andrzej Kolek, Rzeszow University of Technology (Poland)

Wojciech Kucewicz, AGH University of Science and Technology

(Poland) 
Zbigniew Lisik, Łódz University of Technology (Poland)

Lidia Kukasiak, Warsaw University of Technology (Poland)

Bogdan Majkusiak, Warsaw University of Technology (Poland)

Michał Malinowski, Warsaw University of Technology (Poland)

Włodzimierz Nakwaski, Łódz University of Technology (Poland)

Andrzej Napieralski, Łódz University of Technology (Poland)

Regina Paszkiewicz, Wrocław University of Technology (Poland)

Andrzej Pfitzner, Warsaw University of Technology (Poland)

Dorota Pijanowska-Nałęcz, Institute of Biocybernetics and Biomedical Engineering (Poland)

Ryszard Piramidowicz, Warsaw University of Technology (Poland)

Witold Posadowski, Wrocław University of Technology (Poland)

Jacek Radojewski, Wrocław University of Technology (Poland)

Ryszard S. Romaniuk, Warsaw University of Technology (Poland)

Jerzy Rużyło, Penn State University (United States)

Tomasz Stapiński, AGH University of Science and Technology (Poland)

Tomasz Stobiecki, AGH University of Science and Technology

(Poland)

Włodzimierz Strupiński, Institute of Electronic Materials Technology

(Poland)

Jacek Szuber, Silesian University of Technology (Poland)

Marek Tłaczała, Wrocław University of Technology (Poland)

Jerzy Żuk, Maria Curie Skłodowska University (Poland)

\section{Organizing Committee}

Piotr Wiśniowski, Chair, AGH University of Science and Technology (Poland)

Andrzej Brudnik, AGH University of Science and Technology (Poland)

Barbara Dziurdzia, AGH University of Science and Technology (Poland)

Lidia Krawentek, AGH University of Science and Technology (Poland) Łukasz Krzak, AGH University of Science and Technology (Poland)

Anna Małek, AGH University of Science and Technology (Poland)

Wojciech Maziarz, AGH University of Science and Technology (Poland)

Artur Pęcak, AGH University of Science and Technology (Poland)

Artur Rydosz, AGH University of Science and Technology (Poland)

Barbara Swatowska, AGH University of Science and Technology (Poland)

Cezary Worek, AGH University of Science and Technology (Poland) 


\section{Session Chairs}

1 Micro- and Nanoelectronics

Andrzej Napieralski, Łódz University of Technology (Poland)

Tomasz Stobiecki, AGH University of Science and Technology (Poland)

2 Photonics

Maciej Bugajski, Institute of Electron Technology (Poland)

Włodzimierz Nakwaski, Łódz University of Technology (Poland)

3 Microsystems

Jan Dziuban, Wrocław University of Technology (Poland)

Piotr Grabiec, Institute of Electron Technology (Poland)

$4 \quad$ Electronic and Photonic Materials

Marek Tłaczała, Wrocław University of Technology (Poland)

Romuald B. Beck, Warsaw University of Technology (Poland) 
Proc. of SPIE Vol. 10175 1017501-12 Downloaded From: https://www.spiedigitallibrary.org/conference-proceedings-of-spie on 26 Apr 2023
Terms of Use: https://www.spiedigitallibrary.org/terms-of-use 


\section{Introduction}

The Xllth Conference on Electron Technology (ELTE 2016) was held 11-14 September 2016 in Wisła, Poland, and was organized by the Department of Electronics, Faculty of Computer Science, Electronics and Telecommunications of AGH University of Science and Technology in Kraków, Poland.

ELTE 2016 promotes the latest achievements in the widely understood field of electron technology and gathers scientists and exhibitors dealing with electronic and photonic materials and technologies, micro- and nanoelectronics, photonics, and microsystems. Since 1980, when the ELTE conference was held for the first time, the participants meet regularly for ELTE every three or four years.

The main purpose of the conference is to gather scientists enjoying the benefits of electron technology in different fields of interest and provide a forum for presentation of their newest research. Twelve periodic ELTE conferences have been already organized, including ELTE 2016. Listed below are the dates, organizers, and locations of past ELTE conferences:

1980 - Wrocław University of Technology; Karpacz, Poland

1984 - Institute of Electron Technology (later renamed to Institute of

Microelectronics and Optoelectronics), Warsaw University of Technology;

Rynia, Poland

1987 - Institute of Physics, Adam Mickiewicz University in Poznań, Poland

1990 - Institute of Electron Technology, Wrocław University of Technology,

Poland

1994 - Institute of Microelectronics and Optoelectronics, Warsaw University of Technology, Szczyrk, Poland

1997 - Department of Electronics, AGH University of Science and Technology;

Krynica, Poland

2000 - Wrocław University of Technology, Polanica Zdrój, Poland

2004 - Institute of Microelectronics and Optoelectronics, Warsaw University of Technology; Stare Jabłonki, Poland

2007 - Department of Electronics, AGH University of Science and Technology, Kraków, Poland

2010 - Institute of Microsystems Technology, Wrocław University of Technology; Wrocław, Poland

2013 - Institute of Microelectronics and Optoelectronics, Warsaw University of Technology; Ryn, Poland

2016 - Department of Electronics, AGH University of Science and Technology; Wisła, Poland. 
The sessions and topics of ELTE 2016 were:

1) Micro- and Nanoelectronics:

- simulation of technological processes

- electrical, mechanical and thermal design and fabrication of semiconductor devices, integrated circuits and systems

- micro- and nanotechnology (using electron, ion and molecular beams)

- spintronics and magnetoelectronics

- characterization and diagnostics of technological processes of semiconductor devices and integrated circuits

- packaging and assembly of photonic and microelectronic devices and microsystems

2) Photonics

- semiconductor light sources

- plasmonics, photoelectric crystals

- detectors and photovoltaics

- new materials for optical applications

- fiber optics and their applications

- materials with nonlinear optical properties - physics, technology, applications

3) Microsystems

- electrical, mechanical and thermal modeling and design of microsystems

- design and fabrication of MEMS, MOEMS and NEMS

- sensors and smart sensing structures

- lab-on-chip systems

- micro- and nanobiosystems

- integration issues in modern semiconductor technology

4) Electronic and Photonic Materials

- electronic materials

- nanotechnology applications for manufacturing electronic and photonic materials

- bio- and nanomaterials in electronic and photonic devices and microsystems

- advanced methods of characterization of materials and electronic devices

- hybrid and printed circuit boards technology.

Altogether during ELTE 2016, the following presentations were given:

- 8 plenary presentations

- 22 presentations within thematic sessions

- 3 presentations delivered by sponsors

- 75 poster presentations.

We warmly thank the reviewers from the scientific committees, who evaluated the articles and gave valuable remarks to the authors. ELTE 2016 would not exist without the enormous amount of time and effort volunteered by the local organizing committee. 
We are also grateful to the SPIE staff for their continuing active support and valuable advice at every stage.

The next Electron Technology Conference will be organized by Wrocław University of Technology, Poland, in 2019.

Barbara Swatowska Wojciech Maziarz

Tadeusz Pisarkiewicz

Wojciech Kucewicz 
Proc. of SPIE Vol. 10175 1017501-16 Downloaded From: https://www.spiedigitallibrary.org/conference-proceedings-of-spie on 26 Apr 2023
Terms of Use: https://www.spiedigitallibrary.org/terms-of-use 